\title{
The Relationship between Individual Characteristic and Knowledge about HIV/AIDS with Condoms Usage Behaviour on FSWs (FSW)
}

\section{Wahyu Putri Aryska and Laila Ulfa}

Program Study of Public Health, Faculty of Health Science, Universitas Respati Indonesia, Jakarta, Indonesia

\section{Abstract}

In Indonesia, recently heterosexual risk is still a significant cause of HIV transmission (52.7\%), although it has begun to shift to injecting drug users (IDUs). Data elected in 2009 showed that women with AIDS are $38.2 \%$ of them were housewives and $11.7 \%$ of them were Female Sex Worker (FSW). The high figure is thought to be those contracted from risky behavior husbands/partners themselves. The use of condoms is as tool that

Corresponding Author: Wahyu Putri Aryska ulfanns@gmail.com

Received: 26 December 2018 Accepted: 23 February 2019 Published: 7 March 2019

Publishing services provided by Knowledge E

(c) Wahyu Putri Aryska and Laila Ulfa. This article is distributed under the terms of the Commons Attribution License, which permits unrestricted use and redistribution provided that the original author and source are credited.

Selection and Peer-review under the responsibility of the $2 \mathrm{nd}$ International Meeting of Public Health 2016 Conference Committee.

\section{G OPEN ACCESS} can be used by commercial sex workers, both men and women, and can also be used by customers to prevent or Sexually Transmitted Disease (STD) caused by the sexual. This study aimed to determine the relationship between individual characteristics and knowledge about HIVIAIDS with condom usage behavior in FSW. This was a descriptive study with a cross-sectional approach. The population was all FSW in sub-district Community Health Center Duren Sawit. The number of sample in this study as many as 48 FSW. Sampling was done by using population. The data analyzed in univariate and bivariate with Chi-Square test. The results showed that there were $62.5 \%$ of FSW who rarely wore condom; there was a significant relationship among education, marital status, length of work and knowledge about HIVIAIDS with the behavior of using condoms.. Based on the findings, it's suggested for health centers to improve health education activities to prevent the transmission of HIVIAIDS.

Keywords: Knowledge; individual characteristics; behavior; condoms; sex workers

\section{Introduction}

Based on data from South East Asia Regional Office (SEARO) years 2011, India, Indonesia, Myanmar, Nepal, and Thailand were the countries with the highest spread of HIV/AIDS. India ranks in this list with approximately2.4 million population suffering HIVIAIDS while in Indonesia ranks fourth with around 190,000 people with HIV/AIDS (WHO 2012). 
The largest group with HIV/AIDS was detected the productive age between 20-29 years, accounted for around $37.1 \%$ of the whole people living with HIVIAIDS. In low and middle-income countries, HIV prevalence among sex workers was estimated to be12\% (Baral et al. 2012).

The current modes of HIVIAIDS transmission are through heterosexual transmission (61.5\%), Injection of Drugs User (IDU) 15.2\%, and homosexual (2.4\%) (Kemenkes 2016). FSW often share common factors, regardless of their background, that can make them vulnerable to HIV transmission (Shanon et al. 2015).

According to Commission data State AIDS Control Jakarta Timur (2015), the total population of Female Sex Worker (FSW) until March 2016 was accounted as 1,438 people with $4.6 \%$ were having HIV, whereas 48 FSW who worked in area PHC Duren Sawit subdistrict 4.2 with HIV (KPAN 2015). Condom is one of the commonly used by public to prevent transmission some sexually transmitted diseases. According to Provincial AIDS Countermeasures Comission Jakarta's survey, condom usage behavior on FSW in East Jakarta was still low, $30 \%$ of them never used condom and 40 others rarely used condom (KPAN 2010b).

Public Health Centre (PHC) and Non-Government Organizations (NGOs) had been doing counselling on prevention of HIV/AIDS transmission of on the FSW in Duren Sawit area, but in reality, there were only $40 \%$ who use the FSW condoms during the sexual.

\section{Methods}

This study was a quantitative study with use cross-sectional design. The population was a FSW in area of PHC Duren Sawit subdistrict East Jakarta with 48 people as sample. Condom usage behaviour referred to a committed FSW activity by FSW asking their costumer to use a condom during sexual intercourse This study used primary data using questionnaire filled by FSW. Data analysis was conducted using a the Chi-Square test.

\section{Results}

Based on Figure 1, 62.5 \% FSW rarely used condoms during sexual intercourse more than who is rarely using condoms.

As many as $54.2 \%$ of the sample used condoms in sexual intercouse with their customers because of their own willingness: $56.2 \%$ feared of getting a veneral disease and $43.8 \%$ felt condom use was complicated and uncomfortable. 


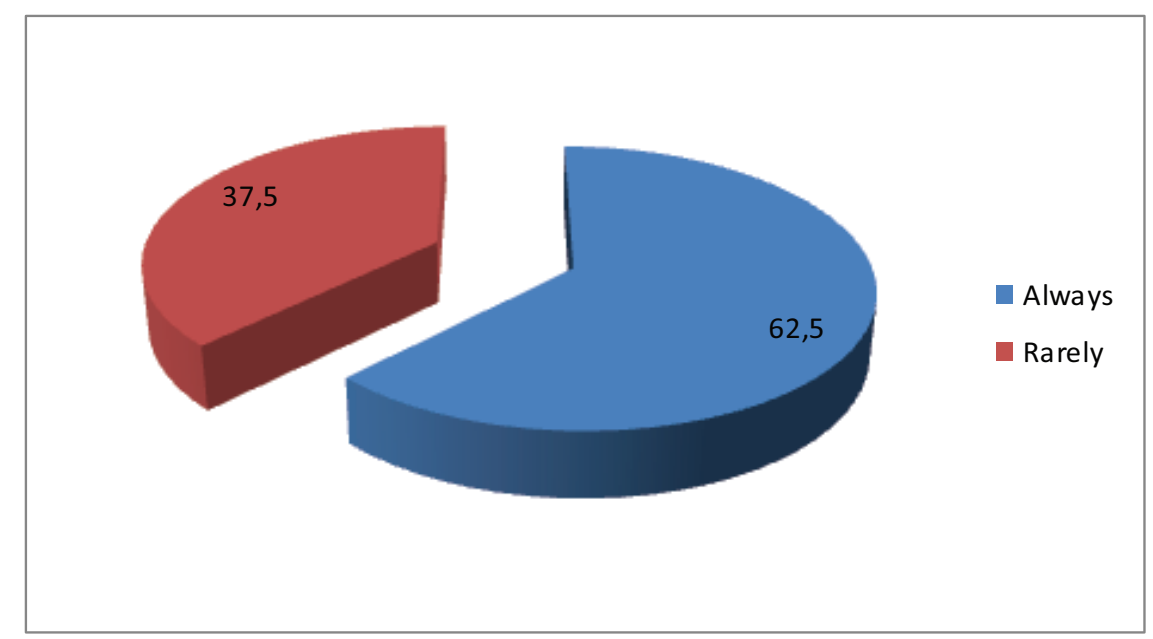

Figure 1: Behaviour Frequency Distribution Use of Condoms the Women Sexual Workers.

TABLE 1: Distribution of Respondents According to Behaviour Condom Usage, characteristics Individu and Knowledge on FSWs.

\begin{tabular}{|c|c|c|c|c|c|c|}
\hline \multirow{3}{*}{$\begin{array}{l}\text { Independent } \\
\text { Variable }\end{array}$} & \multicolumn{4}{|c|}{ Condom Usage } & \multirow{3}{*}{$p$ value } & \multirow{3}{*}{ OR (95\%Cl) } \\
\hline & \multicolumn{2}{|c|}{ Always } & \multicolumn{2}{|c|}{ Rarely } & & \\
\hline & $\mathrm{n}$ & $\%$ & $\mathrm{n}$ & $\%$ & & \\
\hline \multicolumn{7}{|l|}{ Age } \\
\hline Young ( $\leq 24 \mathrm{~s})$ & 7 & 31.8 & 15 & 68.2 & 0.636 & $0.64(0.19-2.08)$ \\
\hline Old (>24s) & 11 & 42.3 & 15 & 57.7 & & \\
\hline \multicolumn{7}{|c|}{ Level of Education } \\
\hline High & 11 & 73.3 & 4 & 26.7 & 0.002 & $10.21(2.47-42.1)$ \\
\hline Low & 7 & 21.2 & 26 & 78.8 & & \\
\hline \multicolumn{7}{|l|}{ Marital Status } \\
\hline Married & 14 & 60.9 & 9 & 39.1 & 0.004 & $8.17(2.0-31.7)$ \\
\hline Not Married & 4 & 16.0 & 21 & 84.0 & & \\
\hline \multicolumn{7}{|c|}{ Length of Work } \\
\hline New Worker & 16 & 57.1 & 12 & 42.9 & 0.002 & $12.0(2.3-61.9)$ \\
\hline Old Worker & 2 & 10.0 & 18 & 90.0 & & \\
\hline \multicolumn{7}{|l|}{ Knowledge } \\
\hline Good & 14 & 70.0 & 6 & 30.0 & 0.001 & $14.0(3.36-58.3)$ \\
\hline Poorly & 4 & 14.3 & 24 & 85.7 & & \\
\hline
\end{tabular}

Table 1 show that the Chi-Square analysis with 5\% alpha and 95\% coincidence, showed that the proportion of older FSW always used a condom (42.3\%) more than younger FSW (31.8\%). Statistical analysis showed that there was no significant relationship between age and condom usage behaviour. While based on the education level, the proportion of FSW who always used condoms was higher (73.3) in the higher educated FSW compared to the low educated FSW (21\%). The result of chi-square found 
a statistically significant relationship between education and condom usage behaviour ( $p$ value 0.002 ) with $O R=10.214$; it means that FSW with higher education had 10.21 times possibility to always wear condom compared to FSW that had low education.

Based on marital status, $47.9 \%$ of the FSW were unmarried, $8.3 \%$ married but not living together, $22.9 \%$ divorced, and $20.8 \%$ died divorce.

The proportion of FSW who were unmarried and always used condom was higher (60.9\%) compared to the FSW who were married (16\%). The results showed that the FSW with unmarried status had 8.16 times possibility to always used condom compared to the married FSW. Other factors associated with condom use behavior was the working period of FSW. FSW who worked $>6$ months was less likely to use condom when having sex with their costumers. The statistic test results indicated that the FSW who worked $\leq 6$ months had a change 12 times to always wear condom during sex compared to FSW that had longer working period. According to their knowledge about safe sexual intecourse, 95.8\% of FSW knew about HIV transmission, HIV risk and 89.6 of them knew how to use condoms. Awarness of HIVIAIDS was also significantly related to condom use behavior. FSW with the good knowledge had 14 times higher chance to always wear condom than FSW with the low education.

\section{Discussions}

Most FSW rarely uses condoms when having sex with their customers. One of the reasons was due to customer desire. Besides, they did not know how to use condoms, because of only $33 \%$ of FSWs who knew how to use a condom. It was different from the result of research that showed that FSW in Semampir Localization, Kediri, 71.2\% of the FSW had condom use behavior (Kristianti 2012). In some cases, sex workers had no access to condoms or were not aware of their importance. In other cases, sex workers were just powerless to negotiate safer sex. Clients might refuse to pay for sex if they had to use a condom and used intimidation or violence to force unprotected sex (Ghimire et al. 2011). The HIV/AIDS transmission prevention program in Indonesia noted that the use of condoms in every sexual intercourse was not useful in preventing the sexually transmission diseases because of the lack of certainty of funding for the condoms provision by the government; there was a policy supporting high public rejection in the condoms provision issue as a means to prevent HIV transmission, and limiting widespread promotion condom use in the community (KPAN 2010a; Silverman et al. 2015). 
Table 1 showed a correlation between condom use behaviour with education, long work, marital status, and knowledge while the variable age was not associated with condom use behaviour. Although there was no association between condom use behaviour with age, old FSW ( $>24$ years) tend to be more likely to use condoms compared to the younger FSW ( $\leq 24$ years). Young sex workers face many of the same barriers to HIV prevention as their older counterparts including their ability to negotiate condom use and legal barriers to HIV and sexual health services. Young sex workers lack access to youth-friendly HIV services. A study from Ukraine found that 20\% of FSWs were 10-19 years old. In parts of sub-Saharan Africa, median HIV prevalence among under $25 \mathrm{~s}$ is reportedly 11\% (Silverman et al. 2015; Mubarak 2011). Age was a factor that influences sexual behaviour and health status. With advancing age, the more mature person in the act included in his sex life.

In the increasing of age, there was an increasing in behavior of maturity, hence the selfprotection behavior by using condoms during sexual intercourse also increases. Other factors influencing the FSW behavior in the condom use was the competition among FSW in getting more costumers. The customers often stated their healthy status, hence they did not need to use condoms. In addition, the education factor is also associated with condom use behavior. Table 1 shows that the FSW with the higher education levels has the opportunity of 10.21 times to always use of condoms compared to FSW with lower education level. Education is the thinking guidance that enable someone to understand something. The higher their education level, the easier for them to receive information (Mubarak 2011).

Low levels of education and illiteracy in women cause a narrow knowledge in women whereas women with higher education level will be easier to accept or seek information. Likewise, with the marital status, unmarried FSW had 8.16 times possibility to always ask a customer to wear condoms compared to married FSW. Unmarried FSW had a higher rate to maintain their healthy sex as they require to use the condoms to their customers. Other studies showed that the working period of the most respondents were less than six months (46.1\%). This could be because they had not been much affected by their environment and the competition levels for the new FSW was usually not as tight as the seniors (Karyati 2014). Experience is one of the factors influencing behavior (Maulana 2009). FSW who had long working period already had regular customers who thought that they had been acquainted with its customers, so they did not think seriously about the importance of condom use as a preventive measure against HIV/AIDS (Hutahean 2010). Good knowledge tends to change attitude and behavior to be better. Good understanding of the respondents was likely caused by HIVIAIDS and condoms counseling from the relevant NGOs. Judging from their answer, in general, FSW had 
already known the HIVIAIDS (58.3\%), its transmission models (95.8\%), people who at risk for HIVIAIDS (93.8\%), how to prevent HIVIAIDS (95.8), how to use condom (87.5\%) and the consequences for not using condoms (83.3\%). From the results obtained, it can be conluded that in general, the FSW knowledge about HIVIAIDS was excellent.

\section{Conclusions}

Condom use behaviour in the FSW was still low, although almost all of the FSW had known about HIVIAIDS. Reasons for not using a condom among them was their own choice, fear of contracting the disease and because they feel uncomfortable. Variable associated with condom use behaviour was education, occupation, marital status, and knowledge. Although age was not a factor related to the condom using behavior, aged FSW were more likely to use condoms.

\section{References}

[1] Baral, Stefan, Chris Beyrer, Kathryn Muessig, Tonia Poteat, Andrea L Wirtz, Michele R Decker, Susan G Sherman, dan Deanna Kerrigan. 2012. "Burden of HIV Among FSWs in Low-Income and Middle-Income Countries; A Systematic Review and MetaAnalysis." The Lancet Infectious Diseases 12 (7): 538-49. http://www.thelancet.com/ journals/laninf/article/PIIS1473-3099\%2812\%2970066-X/abstract.

[2] Ghimire, Laxmi, W Cairns S Smith, Edwin R van Teijlingen, Rashmi Dahal, dan Nagendra P Luitel. 2011. "Reasons for Non-Use of Condoms and Self-Efficacy Among FSWs: A Qualitative Study In Nepal' BMC Women's Health." BMC Women's Health. https://bmcwomenshealth.biomedcentral.com/articles/10.1186/1472-6874-11-42.

[3] Hutahean. 2010. "Hubungan intensitas menawarkan kondom dengan perilaku penggunaan kondom pada seks komersial di Jayapura dan Merauke." FKM UI Depok.

[4] Karyati. 2014. "Tingkat Pendidikan, Usia dan Lama Kerja dengan Konsistensi Pemakaian Kondom Wanita Penjaja Seks di Pati." Jurnal Ilmu Keperawatan dan Kebidanan 5 (1): 64-74. http://ejr.stikesmuhkudus.ac.id/index.php/jikk/article/view/ 218/148.

[5] Kemenkes, Infodatin. 2016. "Situasi Lanjut Usia (Lansia) di Indonesia." Jakarta.

[6] KPAN. 2010a. "Pedoman Program Pencegahan HIV Melalui Transmisi Seksual." Jakarta.

[7] _ 2010b. "Strategi dan Aksi Penanggulangan HIV AIDS Tahun 2010-2014." Jakarta. 
[8] 2015. "Data Layanan di Jakarta Timur 2016." Jakarta Timur.

[9] Kristianti, Shinta. 2012. "Dukungan Wanita Pekerja Seks dan Teman Pelanggan terhadap Penggunaan Kondom tle." Jurnal STIKES 5 (2): 144-54.

[10] Maulana. 2009. Promosi Kesehatan. Jakarta: EGC.

[11] Mubarak. 2011. Promosi Kesehatan Sebuah Pengantar Proses Belajar Mengajar dalam Pendidikan. Yogyakarta: Graha IImu.

[12] Rahmayani, Vicca, Akmal M.Hanif, dan Susila Sastri. 2014. "Hubungan Pengetahuan dan Sikap dengan Tindakan Pencegahan Penularan HIV-AIDS pada Waria di Kota Padang." Jurnal Kesehatan Andalas 3 (2): 238-43. http://jurnal.fk.unand.ac.id/index. php/jka/article/view/99.

[13] Shanon, Kate, Steffanie A Strathdee, Shira M Goldenberg, Putu Duff, Peninah Mwangi, Maia Rusakova, Sushena Reza-Paul, et al. 2015. "Global Epidemiology of HIV Among FSWs: Influence of Structural Determinants.” The Lancet 385 (9962): 55-71. www. avert.org.

[14] Silverman, Jay G., Argentina Servin, Shira M. Goldenberg, Carlos Magis-Rodriguez, Julie Ritter, Anita Raj, dan Kimberly C. Brouwer. 2015. "Adolescent FSWs: Invisibility, Violence, and HIV. Archives of Disease in Childhood." PMC Journal 314 (5): 516-18. https://www.ncbi.nlm.nih.gov/pmc/articles/PMC4890562/.

[15] WHO, UNAIDS. 2012. "Info Terkini Epidemic AIDS." Switzerland. 